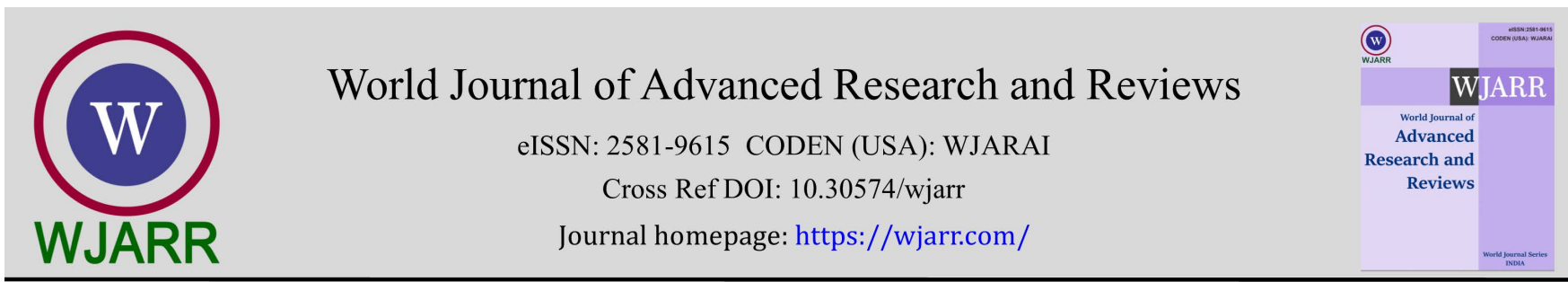

(RESEARCH ARTICLE)

\title{
Estimated average calcium - magnesium content in day meal in a sample of students from Faculty of Medicine of Sarajevo University
}

\author{
Amra Catovic * and Ajla Custovic \\ Faculty of Medicine, University of Sarajevo, Sarajevo, Bosnia and Herzegovina.
}

World Journal of Advanced Research and Reviews, 2021, 09(03), 090-095

Publication history: Received on 02 February 2021; revised on 01 March 2021; accepted on 03 March 2021

Article DOI: https://doi.org/10.30574/wjarr.2021.9.3.0083

\begin{abstract}
Nutrients are chemical substances obtained from food. They have different roles in body. Some are used as energy source, some as structural materials, and regulating agents. Nutrients may reduce the risks of some diseases. There are some recommendations about dietary intake of these nutrients for optimal health. This study aimed to estimate average calcium and magnesium content in day meal in a sample of students from Faculty of Medicine of Sarajevo University. A cross-sectional study was conducted during academic 2015/16 year at Faculty of Medicine of Sarajevo University. The survey covered 44 students. The research instrument was a self-administered questionnaire, by which 3-Day Diet Record was provided. The average intakes of calcium and magnesium were estimated using Nutritional analysis computer program (Nutrics Professional Nutrition Analysis Software). On daily level average intake of calcium was $718.39 \pm 311.14 \mathrm{mg}$ in total sample and average intake of magnesium was $292.57 \pm 310.10 \mathrm{mg}$ in total sample. Average $\mathrm{Ca} / \mathrm{Mg}$ ratio was 2.45. In our sample cheese was top source of calcium with $\mathrm{Ca} / \mathrm{Mg}$ ratio of 32.5 , and bread was top source of magnesium with $\mathrm{Ca} / \mathrm{Mg}$ ratio of 3.1. These results emphasize the importance of monitoring the food nutrition facts in order to achieve adequate nutrients intake.
\end{abstract}

Keywords: Essential Nutrients; Average intake; Recommendation

\section{Introduction}

In the context of nutrition, the minerals are the simplest of the nutrients. A mineral's identity never changes because each mineral is a chemical element, and its atoms are all alike. Besides vitamins, essential fatty acids, and essential amino acids, 16 minerals are essential nutrients [1]. A mineral must satisfy three conditions to be categorized as essential: it is present in human tissues, its total absence causes damage to the vital functions, and supplementation of the element can normalize the reduction in physiological function [2]. The dietary requirement for essential nutrient is defined as an intake level which minimize risk of nutrient deficit or excess [3]. Although indestructible, minerals can be bound by substances that interfere with their absorption, so the bioavailability of minerals varies. Binders include phytates, present in legumes and grains, and oxalates, present in rhubarb and spinach. Absorption of some minerals can be limited because interactions between them, spatially in situation of an excess of one mineral often caused by supplementation. In the group of major minerals, needed in larger amounts are calcium and magnesium. Calcium and magnesium maintain bone health and they are involved in muscle contraction. There is the dynamic interaction between the two minerals helps regulate blood pressure [1].

The most abundant mineral in the body is calcium. Average amount of calcium in the adult reference man, average weigh $70 \mathrm{~kg}$, is approximately $1000 \mathrm{~g}$ [2]. Less than $1 \%$ of total body calcium is needed to support critical metabolic functions like vascular contraction and vasodilation, muscle function, nerve transmission, intracellular signaling and hormonal secretion. The remaining $99 \%$ of the body's calcium constitutes along with phosphate the skeleton. Hormones maintain

\footnotetext{
* Corresponding author: Amra Catovic

Faculty of Medicine, University of Sarajevo, Sarajevo, Bosnia and Herzegovina.
} 
blood concentration of calcium regardless of dietary intake. The bones are remodulated, with continuous resorption and deposition of calcium. When calcium intake is low, the bones suffer. Thus, calcium recommendations are based on the amount needed to retain the most calcium in bones and they vary by age and gender $[1,4,5]$. Net calcium retention is required throughout growth. Populations at risk for calcium deficiency are children during the first 2 postmenopausal women, and, possibly, elderly men. The mean apparent calcium requirement of adults (19-50 yr) in developed countries is about $520 \mathrm{mg}$ (13 mmol). This is increased to some $840 \mathrm{mg}$ (21 mmol) because of urinary calcium lost and insensible losses through skin, hair and nails. This is the basis of the recommended intake for adult of $1000 \mathrm{mg}$ [3]. Milk and milk products are rich natural sources of calcium. The most fortified with calcium are many fruit juices and drinks, tofu, and cereals [5]. Apparently some dark green, leafy vegetables are calcium-rich but actually provide little calcium because they contain binders that limit absorption [1].

Average amount of magnesium in the adult reference man, average weigh $70 \mathrm{~kg}$, is approximately $30 \mathrm{~g}$ [2]. More than half of the body's magnesium is in the bones and the rest is in the muscles and soft tissues, with less than $1 \%$ in blood serum. In addition to maintaining bone health, magnesium participates in hundreds of enzyme systems necessary for energy metabolism. The recommended intake for men (19-30 yr) is $400 \mathrm{mg} /$ day, and for women (19-30 yr) is 310 $\mathrm{mg}$ /day [6]. Average magnesium intakes are below recommendations in general population [7]. Mineral waters may be calcium and magnesium-rich and can be important sources, as well as hard water [1].

The daily relative ratio of calcium and magnesium needed in diet is two parts calcium to one part magnesium. To evaluate risk in different population it is important to estimate how much of these nutrients can be got by food. This study aimed to estimate average calcium and magnesium content in day meal in a sample of students from Faculty of Medicine of Sarajevo University.

\section{Material and methods}

\subsection{Design and Sample}

A cross-sectional study was conducted during academic 2015/16 year at Faculty of Medicine of Sarajevo University. The survey covered 44 students that were familiar with the CINDI dietary guide [8]. The study was conducted according to the research ethics guidelines laid down in the Declaration of Helsinki [9]. Verbal informed consent was obtained from all students before completing the self-administered questionnaire.

\subsection{Data Collection}

The research instrument was a self-administered questionnaire, which consisted of two parts. In the first part of the survey, questions were related to age, sex, weight, height. The second part of the survey referred to 3-Day Diet Record [10]. A record of all foods and beverages consumed over a three-day period (consecutive days) included detailed information about each meal. Individual foods and their quantities contained in the three-day meal were entered into a computer program (free version of Nutritics Professional Nutrition Analysis Software) which provided information of single nutrient intake.

Self-reported height and weight were used to calculate BMI $(\mathrm{kg} / \mathrm{m} 2)$. According to guidelines stated by the World Health Organization [11] weight status was classified into four categories: under-weight (BMI $\leq 18.5$ ), normal weight (BMI between 18.5-24.9), overweight (BMI between 25-29.9), and obese (BMI $\geq 30$ ).

\subsection{Data Analysis}

Statistical analyses were performed using the Statistical Package for Social Sciences (version 13.0, SPSS, Inc) software. Continuous data were presented as mean and standard deviation (SD) and compared using Student t-test. Differences were considered statistically significant at $\mathrm{P}<0.05$. 


\section{Results}

A sample included a total of 44 students (Table 1).

Table 1 Characteristics of students participated in the study.

\begin{tabular}{|l|l|}
\hline Variable & Total \\
\hline Number of students (\%) & $44(100.00)$ \\
\hline Number of males (\%) & $15(34.09)$ \\
\hline Number of females (\%) & $29(65.91)$ \\
\hline Age (means \pm SD) & $26.55 \pm 3.53$ year \\
\hline Weight (means \pm SD) & $74.64 \pm 15.80 \mathrm{~kg}$ \\
\hline Height (means \pm SD) & $174.34 \pm 9.36 \mathrm{~cm}$ \\
\hline BMI (means \pm SD) & $24.33 \pm 3.37 \mathrm{~kg} / \mathrm{m}^{2}$ \\
\hline
\end{tabular}

Students' nourish status is showed by Table 2

Table 2 Students' nourish status based on BMI categories.

\begin{tabular}{|c|c|c|c|c|c|c|}
\hline \multirow[t]{2}{*}{ Students } & \multicolumn{2}{|c|}{$\begin{array}{l}\text { Normal (BMI between } \\
18.5-24.9 \mathrm{~kg} / \mathrm{m}^{2} \text { ) }\end{array}$} & \multicolumn{2}{|c|}{$\begin{array}{l}\text { Overweight (BMI between } \\
25-29.9 \mathrm{~kg} / \mathrm{m}^{2} \text { ) }\end{array}$} & \multicolumn{2}{|c|}{$\begin{array}{l}\text { Obese class I (BMI between } \\
30.0-34.9 \mathrm{~kg} / \mathrm{m}^{2} \text { ) }\end{array}$} \\
\hline & $\mathrm{N}^{\circ}$ & $\%$ & $\mathrm{~N}^{\circ}$ & $\%$ & $\mathrm{~N}^{0}$ & $\%$ \\
\hline Males & 3 & 20.00 & 12 & 80.00 & - & - \\
\hline Females & 21 & 72.41 & 7 & 24.14 & 1 & 3.45 \\
\hline Total & 24 & 54.55 & 19 & 43.18 & 1 & 2.27 \\
\hline
\end{tabular}

More than half of the students (54.55\%) were of normal weight, whereas 197 (43.18\%) students were overweight, and $1(2.27 \%)$ was classified as obese class I.

The analysis of the calcium intake revealed that on daily level average intake was $718.39 \pm 311.14 \mathrm{mg}$ in total sample (Table 3).

Table 3 Calcium intake

\begin{tabular}{|l|l|l|l|l|}
\hline \multirow{2}{*}{ Students } & \multicolumn{2}{|l|}{ Calcium intake $(\mathbf{m g})$} & \multirow{2}{*}{ p } \\
\cline { 2 - 4 } & Total & $\mathrm{BMI}<25 \mathrm{~kg} / \mathrm{m}^{2}$ & $\mathrm{BMI} \geq 25 \mathrm{~kg} / \mathrm{m}^{2}$ & \\
\hline Males & $825.73 \pm 291.29$ & $881.33 \pm 198.32$ & $811.83 \pm 315.89$ & 0.726 \\
\hline Female & $662.86 \pm 311.25$ & $648.43 \pm 252.58$ & $700.75 \pm 450.52$ & 0.764 \\
\hline P & 0.100 & 0.143 & 0.523 & \\
\hline All & $718.39 \pm 311.14$ & $677.54 \pm 255.12$ & $767.40 \pm 368.33$ & 0.346 \\
\hline
\end{tabular}

There was no statistic significant difference in calcium intake according to nourish status or gender. 
The analysis of the magnesium intake revealed that on daily level average intake was $292.57 \pm 310.10 \mathrm{mg}$ in total sample (Table 4).

Table 4 Magnesium intake.

\begin{tabular}{|l|l|l|l|l|}
\hline \multirow{2}{*}{ Students } & \multicolumn{3}{|l|}{ Magnesium intake $(\mathbf{m g})$} & \multirow{2}{*}{ p } \\
\cline { 2 - 5 } & Total & $\mathrm{BMI}<25 \mathrm{~kg} / \mathrm{m}^{2}$ & $\mathrm{BMI} \geq 25 \mathrm{~kg} / \mathrm{m}^{2}$ & \\
\hline Males & $293.33 \pm 84.10$ & $293.00 \pm 8.89$ & $299.67 \pm 94.75$ & 0.908 \\
\hline Female & $289.59 \pm 379.62$ & $310.24 \pm 445.71$ & $235.38 \pm 64.92$ & 0.644 \\
\hline P & 0.931 & 0.946 & 0.112 & \\
\hline All & $292.57 \pm 310.10$ & $308.09 \pm 415.67$ & $273.95 \pm 88.29$ & 0.721 \\
\hline
\end{tabular}

There was no statistic significant difference in magnesium intake according to nourish status or gender.

Based on determined average intake of calcium and magnesium, we calculate ratio between these nutrients (Table 5).

Table 5 Ratio between calcium and magnesium.

\begin{tabular}{|l|l|l|l|}
\hline \multirow{2}{*}{ Students } & \multicolumn{3}{|l|}{ Ratio Ca/Mg } \\
\cline { 2 - 4 } & Total & $\mathrm{BMI}<25 \mathrm{~kg} / \mathrm{m}^{2}$ & $\mathrm{BMI} \geq 25 \mathrm{~kg} / \mathrm{m}^{2}$ \\
\hline Males & 2.82 & 3.00 & 2.71 \\
\hline Female & 2.88 & 2.09 & 2.98 \\
\hline All & 2.45 & 2.20 & 2.80 \\
\hline
\end{tabular}

Top sources of calcium and magnesium have different ratio between these nutrients (Table 6).

Table 6 Souses of calcium and magnesium in sample of medical students.

\begin{tabular}{|l|l|l|l|}
\hline Food & $\begin{array}{l}\text { Ca } \mathbf{m g}) \text { in } \mathbf{1 0 0} \mathbf{~ m g ~ / ~} \\
\mathbf{1 0 0} \mathbf{~ m l}\end{array}$ & $\begin{array}{l}\text { Mg (mg) in } \mathbf{1 0 0} \mathbf{~ m g} / \\
\mathbf{1 0 0} \mathbf{~ m l}\end{array}$ & Ratio Ca/Mg \\
\hline Cheese & 974 & 30 & 32.5 \\
\hline Milk & 120 & 12 & 10.0 \\
\hline Bread & 125 & 40 & 3.1 \\
\hline Mineral water & 33 & 11 & 3.0 \\
\hline Chicken & 14 & 23 & 0.6 \\
\hline
\end{tabular}

In our sample nuts were rarely consumed during period of research.

\section{Discussion}

The purpose of this study was to estimate average calcium and magnesium content in day meal in a sample of students from Faculty of Medicine of Sarajevo University. A sample included 44 students, of which 15 (34.09\%) were male and $29(65.91 \%)$ were female. More than half of the students (54.55\%) were of normal weight, whereas 197 (43.18\%) students were overweight, and $1(2.27 \%)$ was classified as obese class I. On daily level average intake of calcium was $718.39 \pm 311.14 \mathrm{mg}$ in total sample. There was no statistic significant difference in calcium intake according to nourish status or gender. On daily level average intake of magnesium was $292.57 \pm 310.10 \mathrm{mg}$ in total sample. There was no statistic significant difference in magnesium intake according to nourish status or gender. Average $\mathrm{Ca} / \mathrm{Mg}$ ratio was 
2.45. In our sample cheese was top source of calcium with $\mathrm{Ca} / \mathrm{Mg}$ ratio of 32.5 , and bread was top source of magnesium with $\mathrm{Ca} / \mathrm{Mg}$ ratio of 3.1 .

There are some recommendations about dietary intake of these nutrients for optimal health. These recommendations for publics are incorporated on food labels. On food labels nutrient information is present in two ways-in quantities (such as grams) and as percentages of standard called the Daily Values. The Daily Values, a 2000-kcalorie diet, is considered about right for sedentary younger women, active older women, and sedentary older men [1]. Some recommendations are update. Original Daily Value for calcium was 1000, and it is updated to 1300 mg. Original Daily Value for calcium was 400, and it is updated to $420 \mathrm{mg}$ [12]. Average intakes of calcium and magnesium in our sample were bellow these recommendations. When calcium intake is low calcium can be taken from the bone to maintain normal biological functions. With time, osteopenia would develop with an increased risk of osteoporosis and bone fractures [5]. All bones can be affected by the disease, but the bones of the spine, hip, and wrist are most likely to break [13]. Urinary excretion of magnesium can be limited in situation of low magnesium intake [14]. However, habitually low intakes can cause muscle weakness, involuntary muscle contraction, sleepiness [6]. The risk of numerous types of cardiovascular disease is increased due to subclinical magnesium deficiency [15].

Daily calcium supplement intake in some population has been increased as result of awareness about osteoporosis risk [16]. However, calcium from supplements might increase the risk of cardiovascular disease [17,18]. Suboptimal intake of magnesium is present in general population [19]. This fact open discussion about consuming of fortified foods and dietary supplements, although it is emphasized that nutritional needs should be met primarily from foods and beverages - specifically, nutrient-dense foods and beverages [20]. There are some suggestions that a ratio of $\mathrm{Ca} / \mathrm{Mg}$ is more important than the absolute quantity of calcium, or magnesium in the diet and a ratio of approximately 2-to-1 is considered healthy [16]. To achieve this ratio in diet abended with diary some food groups can be introduced in diet, like nuts.

\section{Conclusion}

The use of a small sample is limitation of this study. However, results emphasize the importance of monitoring the food nutrition facts in order to achieve adequate nutrients intake.

\section{Compliance with ethical standards}

\section{Acknowledgments}

The authors would like to thank the participants who involved in this study.

\section{Disclosure of conflict of interest}

The authors declare that they have no competing interests.

\section{Statement of ethical approval}

All procedures performed in the study involving human participants were by the research ethics guidelines laid down in the Declaration of Helsinki.

\section{Statement of informed consent}

Informed consent was obtained from all individual participants included in this study.

\section{References}

[1] Whitney EN, Rolfes SR. Understanding Nutrition, 15th edition. Wadsworth Cengage. 2017.

[2] Zoroddu MA, Aaseth J, Crisponi G, Medici S, Peana M, Nurchi VM. The essential metals for humans: a brief overview. J. Inorg. Biochem. 2019; 195: 120-29.

[3] World Health Organization \& Food and Agriculture Organization of the United Nations. Vitamin and mineral requirements in human nutrition, second edition. Geneva. 2004. 
[4] Committee to Review Dietary Reference Intakes for Vitamin D and Calcium, Food and Nutrition Board, Institute of Medicine. Dietary Reference Intakes for Calcium and Vitamin D. Washington, DC: National Academy Press, 2010 .

[5] US National Institutes of Health, Office of Dietary Supplements. Calcium: Fact Sheet for Health Professionals., 2020.

[6] US National Institutes of Health, Office of Dietary Supplements. Magnesium: Fact Sheet for Health Professionals. 2020.

[7] Rude RK, Singer FR, Gruber HE, Skeletal and hormonal effects of magnesium deficiency, Journal of the American College of Nutrition. 2009; 28: 131-141.

[8] World Health Organization/Regional Office for Europe. CINDI dietary guide. Copenhagen 2000.

[9] World Medical Association. World Medical Association Declaration of Helsinki: Ethical Principles for Medical Research Involving Human Subjects. JAMA. 2013; 310(20), 2191-2194.

[10] Thompson FE, Subar AF. Dietary assessment methodology. Nutr Prev Treat Dis. 4th ed. 2017.

[11] World Health Organization. Obesity. Preventing and managing the global epidemic. Report on a WHO consultation on Obesity. Geneva. 2000.

[12] Food and Drug Administration. Daily Value on the New Nutrition and Supplement Facts Labels. 2020.

[13] WebMD. Understanding Osteoporosis -- the Basics. 2021.

[14] Swaminathan R. Magnesium Metabolism and its Disorders. Clin Biochem Rev. 2003; 24(2): 47-66.

[15] Di Nicolantonio JJ, O'Keefe JH, Wilson W. Subclinical magnesium deficiency: a principal driver of cardiovascular disease and a public health crisis. Open Heart 2018; 5: e000668.

[16] Kelly 0, Gilman J, Ilich J. Utilizing Dietary Micronutrient Ratios in Nutritional Research May be More Informative than Focusing on Single Nutrients. Nutrients. 2018; 10(1): 107.

[17] Michaelsson K, Melhus H, Warensjo Lemming E, Wold A, Byberg L. Long term calcium intake and rates of all cause and cardiovascular mortality: community based prospective longitudinal cohort study. BMJ 2013; 12; 346: f228.

[18] Li K, Kaaks R, Linseisen J, Rohrmann S. Associations of dietary calcium intake and calcium supplementation with myocardial infarction and stroke risk and overall cardiovascular mortality in the Heidelberg cohort of the European Prospective Investigation into Cancer and Nutrition study (EPIC-Heidelberg). Heart. 2012; 98: 920-5.

[19] US Department of Agriculture, Agricultural Research Service. Usual Nutrient Intake from Food and Beverages, by Gender and Age, What We Eat in America, NHANES. 2013-2016; 2019.

[20] US Department of Agriculture and U.S. Department of Health and Human Services. Dietary Guidelines for Americans, 2020-2025. 9th Edition. December 2020. 